\title{
Product Development And Cost Management Using Target Costing: A Discussion And Case Analysis
}

Mehmet C. Kocakülâh, ( Email: mkocakul@usi.edu), University of Southern Indiana A. David Austill, (Email: daustill@uu.edu), Union University

\begin{abstract}
This paper discusses the use and process of target costing for product development and cost management and why it should be used in product planning. To explain the target costing process, benefits, and problems with its use, the authors utilize a case study of a poultry processing company manufacturing home meal replacements for sale through supermarkets.
\end{abstract}

\section{INTRODUCTION}

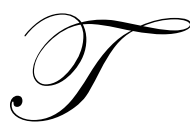

he target costing concept grew out of a need for manufacturers to improve product cost management and product development. The traditional cost management, cost accumulation and allocation methods used for decades and still predominant in the manufacturing and services sectors have failed as tools for product development, planning, and cost management. This is because they focus on the product's cost rather than on the expectations of customers and the product design itself. Furthermore, traditional cost systems inundate managers with accounting reports that routinely overstate the cost of high-volume, standardized products and understate the costs of lowvolume, customized products. (Lockamy III and Smith, 2000).

Traditional methods are not forward-looking. They do not consider the need for the cost, what drives the cost, or even if the process or product characteristic/function, is, in fact, necessary. The needs and desires of customers, other than the cost of the product, are ignored in traditional methods. What results too often are overengineered products that don't match the customer requirements and are priced incorrectly. (Butscher et al, 2000) The supply chain aspects are not regarded with as much importance as they deserve in product planning and costing. In traditional cost management, the company focuses on the lowest cost effect per unit in the selection of suppliers, distribution channels and methods, and production methods.

The need to improve productivity and product quality resulted in many companies adopting new cost management methods, including activity-based cost management, kaizen costing, just-in-time inventory management, total quality management, and target costing. (See Lockamy and Smith, 2000). Of the foregoing cost or management methods, target costing stands alone as the best means to enhance product development, pricing, and management of production and selling costs. This paper argues for greater use of target costing.

\section{Characteristics Of Target Costing}

Target costing has been defined by the Consortium for Advanced Manufacturing -- International as a set of management tools and methods designed to (1) direct design and planning activities for new products, (2) provide a basis for controlling subsequent operational phases, and (3) ensure that products achieve given profitability targets throughout their life cycle. (Cf. Shank, 1999). Cooper and Slagmulder describe it as a process for ensuring that a product launched with specified functionality, quality, and sales price can be produced at a life-cycle cost that generates a satisfactory level of profitability. (Cf. Lockamy and Smith, 2000). 
The process is design-centered and has a market driven focus, which, unlike the conventional cost management techniques, allows firms to trade off quality and functionality to achieve target costs as a last resort. (Castellano et al, 2003) It actually focuses less on costs and more on customer requirements. The question is not "How much will the product cost?," but "How much can the product cost?" Karo describes target costing as a complete cost-reduction program, not a simple cost-reduction technique, but a complete, strategic profit management system. Horvath describes it as a part of the cost-management function for a product throughout its life cycle. (Cf. Shank, 1999) The key elements of the process is that it is a planning tool where aspects of the product, cost and otherwise, are considered over the product's whole life cycle. Also, it is a cross-functional process, much like good strategic planning.

Who uses target costing? Toyota developed the concept in the 1960s. It is used more in Japan than anywhere else in the world. Lockamy and Smith report that in the early 1990s over 80 percent of Japanese assembly manufacturing firms were using target costing, including all firms in the Japanese transportation equipment industry but none in the paper and pulp industry. (Lockamy and Smith, 2000)

The rest of the world has not as readily adopted target costing, although many companies adopt certain aspects of it. It has been particularly slow to be adopted in the U.S. Banham reports that in the year 2000 only about 65 U.S. firms utilized target costing. Of these, 85 percent were discrete-parts and finished-product manufacturers. Some of these firms include Boeing, Eastman Kodak, Caterpillar, and Daimler-Chrysler. A survey of those U.S. firms reveal favorable, although not exceptional, results from utilizing target costing. (See the survey results in Banham, 2000.) Peter Zampino, director of research at Consortium for Advanced Manufacturing -- International (CAM-I), noted that U.S. firms tend to adopt target costing when they are in crisis mode. In his opinion, U.S. firms tend to have the opinion that in good economic times a company does not need target costing. (Banham, 2000) U.S. firms like the concept of cost management, and many utilize the techniques described in this paper, but they do not follow the disciplined target costing process and the cross-functional participation in product, production, and supply chain planning activities. (Banham, 2000)

Dekker and Smidt surveyed 32 Dutch manufacturing firms, all of which were listed on the Amsterdam stock exchange. They found that 19 of the 32 firms used practices similar to the Japanese target costing model. Those Dutch firms did not call their process "target costing", and they developed their respective practices independently of the Japanese practices. (Dekker et al, 2003)

Target costing could be used by service companies, although those companies still tend to be cost-plus oriented. The construction industry has not accepted this new approach either. Its pricing nature is usually driven by costs or $\square$ topdown $\square$ estimating based on rates for building elements, such as price per square foot. (See Niconini et al, 2000, for analysis of two case studies of construction firms in Great Britain. See also Perry et al, 2000, for a discussion of target cost contracting which utilizes some features of target costing.)

\section{Developing New Products}

Product development has grown more and more important as a necessity to stay competitive, especially with global competition. Products must be profitable during their life cycle before the decision should be made to allow the product to come to market. Target costing can be an integral part of the product development process as it makes cost an input to the product development process rather than an outcome of it. (Cooper et al, 1999) Because target costing is forward-looking and is an integrated, cross-functional activity, it is most effective when it is implemented early in the product planning process. The authors' case study will illustrate the importance of target costing in planning new products.

\section{TARGET COSTING PROCESS}

The target costing process is composed of a number of discrete activities and decisions. It begins with a determination of the product, its characteristics and qualities, and its optimal selling price. This is probably the most important step in the process. The product itself will ultimately determine the costs necessary to produce and sell that 
product. Butscher and Laker describe this first step as including (1) definition of the target segments, (2) identification of the competitive advantages and disadvantages, (3) positioning of the new product within the target segments, (4) finetuning the product design and pricing, and (5) market simulations. (Butscher et al, 2000)

Market research is an essential element of this first step. Whether done within or outside the firm, market research should focus on the desires and concerns of the customer. What does the customer want? What design features does the customer like or dislike, need or doesn't need. The customer's perceptions as to quality, price, and value are also important. The marketing research is used to determine the price customers are willing to pay for the product, given its functionality, quality, and the substitute products offered by competing firms. (Lockamy and Smith, 2000) The information obtained from the customer will allow product designers to focus on those desired qualities and features. However, the product must be forward-looking and incorporate new features and salient product characteristics to assure product differentiation and a reasonable product life.

The target selling price is determined based on the market for the product as designed. Obviously, when a manufacturer sells its products in more than one market or through different channels, it may sell the same product at different prices. For example, pharmaceuticals manufactured in the U.S. are exported at lower prices to sellers in Canada and Mexico than they are sold for in the U.S. In such case an average selling price should be used. (Cooper et al, 1999)

The second step in the process is the determination of the desired profit or target profit margin. Profits and profit margin should be reasonable and cover planned costs, additional required investment, decommissioning or disposal costs over the product's life cycle. Similarly, the profit margin should be sufficient to support continuing product research and development. (Lockamy and Smith, 2000) Some companies, for example, Sony Corporation, build in more flexibility in establishing the desired profit or target profit margin. There, they allow for tradeoffs between different products, i.e., within the product group some products will have some profit margins higher and some lower. (Cooper et al, 1999) The desired profit margin should be based on, and meet, the company's objectives or policies.

Computation of the allowable product cost is the third step in the process. The allowable product cost is the difference between the target selling price and the target profit margin. The objective is to meet the cost constraints placed on the company, or as Cooper and Slagmulder describe it, establishing the target cost reduction objective.

The fourth step in the target costing process is determining the nature and amount of the product manufacturing and marketing costs and actually assuring itself that it can attain those target costs. These costs cannot exceed the allowable product costs, unless extenuating circumstances, such as a targeted product release date, dictate proceeding with the product before sufficient costs reductions are obtained. This part of the target costing process ends when the firm discovers a way to satisfy the customer requirements at the target cost or when the product is abandoned. (Lockamy and Smith, 2000)

What has been the company's past production and marketing costs? Will new cost savings be required? What will be the effect of product revisions? In what areas can one reasonably expect cost savings? How soon must the product be released? Will the allowable cost require modifications in the supply chain? These are just some issues that may arise in proceeding through the process. Because from time-to-time there are unexpected cost overruns due to design-related problems in the production process, a company may build in a "cushion" or "reserve for the production manager" of 5-10 percent to cover such costs.

In determining what costs are necessary and identifying ways to reduce costs, a company may use other cost management techniques like value engineering, benchmarking, design for manufacture and assembly, and quality function deployment. (Cooper et al, 1999) Also, continuous cost reduction may be available through kaizen costing. Integration of the various functions, such as accounting, purchasing, marketing, production, logistics, and engineering in planning activities will be necessary here to reduce unnecessary costs and work processes. As the target costing approach is a crossfunctional team approach, initially it is time extensive but the payoff for the additional planning costs should come later in savings in production and the supply chain activities. Notwithstanding that cost reduction is usually favorable, in target costing cost rationalization, not cost minimization, is the goal. This is consistent with techniques like value engineering, 
which is performed to redesign the product, its manufacturing process, and its distribution and service systems. (Lockamy et all, 2000)

Cooper and Chew argue that a product's cost needs to be subjected to the scrutiny of the marketplace from the beginning of the development activity. (Cooper et al, 1996) Benchmarking helps avoid the arbitrariness in target costing in such situations as internal subassembly and can help to reduce costs, especially when value engineering is used early in the product/production development stage. (Clausing, 1996) In addition, benchmarking provides a tool for measuring the effectiveness of target costing. For example, Eastman Kodak set a benchmark of a 10:1 return on the costs associated with implementing target costing. If it cost the company $\$ 100,000$ to have an engineer work closely with customers in product design, the return on that activity would have to generate at least $\$ 1$ million in cost reductions. (Banham, 2000)

Cost reductions should be sought in the manufacturer's internal activities and external sourcing. Although a manufacturer has significant legal and ethical obligations in maintaining safety and health of its employees, customers, and users of its products, and legal and regulatory requirements become more and more onerous every year, companies must cut costs wherever possible. Sometimes, however, cost savings are just not possible, and the product characteristics must be scrutinized again to isolate cost savings.

The supply chain should be scrutinized and utilized for cost reduction opportunities. The supply chain is much more important for companies utilizing target costing. Ellram notes that supply management and the purchasing function is particularly critical at the initial stages of the target costing process when developing component-level target costs and when activities and modifications are occurring to achieve target costs. Furthermore, supply management can play a very important role in managing, monitoring and improving costs in the supply chain. (Ellram, 2002)

When acquiring component parts or necessary services, supply management may find it necessary to work more closely with suppliers. Additional cost savings may be achievable by creating trading partner relationships with the suppliers. The manufacturer's chief engineer or product manager might try to assist or provide incentives for a supplier to redesign a part or production process to achieve cost savings. Moreover, the company and the supplier may collaborate to develop and improve products and enhance the value and satisfaction provided to customers. (Lockamy and Smith, 2000; Banham, 2000)

The trading partner relationship may create administrative cost savings through EDI, B-2-B (business-to-business) transactions, or by providing incentives or rewards for devising creative cost reduction measures. (Cooper et al, 1999; Lockamy and Smith, 2000) In order to maintain the trading partner relationship, however, the company must allow the supplier-trading partner to receive a reasonable compensation making continuation as a trading partner worthwhile. The trading partners, including the company utilizing target costing, must be assured of profitability and survivability. (Lockamy and Smith, 2000)

This part of the target costing process is iterative. Costs are estimated determined for the product as designed. It may be necessary to reconsider certain of the design features given the cost factors. A determination would then have to be made to delete the product feature or to revise it, which would require another review of the production and supply chain processes and costs.

Finally, the target costing process requires monitoring to make sure the process has been effective. Products must be changed from time-to-time and new products added to existing product lines, and these activities will require product and cost planning as well.

\section{CASE EXAMPLE -- CRANDON FARMS}

\section{Hmrs And The Industry}

Home meal replacement (HMR), also known as 'meal solutions', products appear to be the newest trend in the 
food industry for grocery stores. In addition to affordable prices, product characteristics such as convenience, quality, quick and easy are salient product characteristics important to consumers in that particular product market.

HMR is not a new concept in the food industry. Fast food restaurants have been capitalizing on this market for some time. Over the years, grocery store chains have started to recognize that these fast food places have been taking away dollars from their business. Today, consumers spend 53 cents out of every food dollar at grocery stores, down from 62 cents in 1976. This translates to over $\$ 60$ billion lost in potential sales. BOSTON MARKET ${ }^{\text {TM }}$ has been the most successful in recent years in providing the consumer a complete take-home meal for a good value. Its marketing is targeted at working parents with two incomes. These parents want meals that can be brought home and are quick and relatively cheap. Grocery stores have introduced deli products and rotisserie items that are ready to eat to help slow down the loss of market share to fast food restaurants.

Grocery store chains turned to the meat and poultry companies and asked them to develop new products that can compete against firms like BOSTON MARKET ${ }^{\mathrm{TM}}$. This new concept of thinking by the meat and poultry industry is still relatively in its infancy. There have been many HMR products introduced in grocery stores in the past several years; however, most of them have failed within the first 12 months after introduction. Part of the problem is trying to determine what the consumer really wants. It is known that 60 percent of consumers on any given day do not know what they are going to cook for dinner that night. Therefore, a quick, nutritious, good-tasting, and relatively cheap meal prepared in less than 10 minutes is the type of product HMR manufacturers or food processors require.

\section{The Company And The Product}

Crandon Farms (Crandon) is an actual, fully diversified poultry company that is not in the business of packaging ingredients other than poultry. The company name, Crandon Farms, is fictitious and is used instead of the company's actual name for confidentiality and privacy purposes. Crandon was asked by consumers and some retail grocery chains carrying its products and consumers to develop with an exciting HMR line maintaining the quality and value customary of Crandon Farms products. The company answered this challenge. In February 1997, Crandon Farms introduced Café CRANDONTM as its HMR product line for retail consumers.

\section{Café Crandon ${ }^{\mathrm{TM}}$ Objectives}

The Café CRANDONTM HMR line was designed to develop a new product category for Crandon and for the retailers to address the HMR trend. By providing a unique positioning versus the competition, this single-serve entrée line would help reduce the loss of market share caused by consumer's money being spent outside the grocery store chains for quick meals. In turn, the consumer would have a unique choice for dinner that could be served at home and prepared in less than 10 minutes.

Café CRANDONTM would effectively address the needs and desires of the market and the following three important current consumer trends:

1. A package containing ready-to-eat or ready-to-cook foods for a complete meal has grown 56\% between 1991 and 1995.

2. Parents want their family to eat together and Café CRANDON ${ }^{\mathrm{TM}}$ provides a sit-down meal.

3. Café CRANDON is particularly favorable with those consumers hoping to perpetuate family values. (Research Alert, 1996)

\section{Café CRANDON ${ }^{\mathrm{TM}}$, The Product}

Concept -A line of FRESH Meal Kits containing chicken, starch, sauce, and possibly vegetables which allows the consumer to "prepare" a home-cooked meal in minutes. Three easy steps to a high-quality meal.

Positioning - A kit (i.e., separate compartments, some assembly required), containing multiple servings, which is 
convenient and easy. Allows the consumer to nurture family by $\square$ cooking. $\square$ Must contain high-quality chicken from CRANDON, featuring the line SHORT CUTS ${ }^{\mathrm{TM}}$ Breast Meat and containing more chicken than the competition, especially in the single-serve entrees.

Café CRANDONTM HMRs would be available in three flavors, fettuccine Alfredo, Fajitas, and stir fry. Servings per kit vary between three and four. Although the United States Department of Agriculture (USDA) originally wanted the product's package to state that it contained between eight and nine servings, Crandon successfully argued for the package to be described as containing three to four servings. A complete identification of the product is found in Appendix 1.

Café CRANDONTM HMRs cook in as little as two minutes with three very easy steps. As Crandon is known to be a fresh products company, Café CRANDON ${ }^{\mathrm{TM}}$ HMRs were developed to be fresh, never frozen. Few HMR products are not frozen. The variety of three flavors allowed the consumer to have a choice for a quick home-cooked meal. By offering three flavors, it also allowed the retailer to broaden its HMR line and to entice repeat buyers to try other flavors.

Café CRANDONTM is a family-sized meal that is complete in the box. The average size family is defined as two parents and one child. The meal is low in fat and contains no MSG. The product market required Café CRANDONTM HMRs to have a retail price under $\$ 10$ to keep them price competitive.

Café CRANDONTM's targeted consumers are women 25 to 54 (with or without children) with household incomes of $\$ 50,000$ or more. Such persons are commonly under time constraints and make decisions on family meals quickly.

\section{Market Research For Café CRANDONTM Hmrs}

Before introducing Café CRANDONTM, Crandon did extensive research, the results of which are beyond the scope of this paper. However, some important aspects of the market research follow, which will help the reader better understand the decisions made for this product.

The Café CRANDONTM product was validated by using Home Use Test (HUT), which involved 100 consumer families that prepared the products at home. Also, four focus groups were utilized after the HUT to determine the results. The findings from these two tests revealed that 9 out of 10 respondents rated Café CRANDONTM HMRs as useful to their households. On a scale of 1 to 10, Café CRANDON rated a 7.4, with $61 \%$ of the consumers indicating future purchase intent. Two out of three respondents indicated they would use the HMR to replace a take-out food meal for their household. Consumers liked the name and the package design, an important step in getting the first-time buyer to try this product.

\section{Retailer Margins And Costs}

Below are sheet prices, non-feature business, for Café CRANDONTM HMRs. Due to different net weights of the products, all costs are broken down by cost per pound, unless indicated otherwise. Note the abbreviations: fettuccine Alfredo $=$ FA, Fajitas $=$ F, and stir fry $=$ SF .

Sales had been decreasing due to lack of satisfactory gross margins for retailers. With these low margins, many stores were not willing to carry the product on a regular basis.

\begin{tabular}{|c|c|c|c|c|c|c|}
\hline Product & Kit Weight & Cost & Cost/Unit & Retail/Unit & Gross \$ & Margin \% \\
\hline FA & $2.00 \mathrm{lb}$. & $\$ 3.49$ & $\$ 6.98$ & $\$ 9.99$ & $\$ 3.01$ & $30 \%$ \\
\hline F & $1.94 \mathrm{lb}$. & $\$ 3.49$ & $\$ 6.77$ & $\$ 9.99$ & $\$ 3.22$ & $32 \%$ \\
\hline SF & $2.06 \mathrm{lb}$. & $\$ 3.49$ & $\$ 7.19$ & $\$ 9.99$ & $\$ 2.80$ & $28 \%$ \\
\hline
\end{tabular}


The company needed to address the low gross margins for retailers who sold Café CRANDONTM. Most retailers require at least a $30 \%$ gross margin and on value-added items, such as Café CRANDONTM HMRs, a $35 \%$ to $40 \%$ gross margin is preferred. Thus, the retailer's gross margin had to be increased through some means without increasing the product's retail price. Café CRANDON ${ }^{\mathrm{TM}}$ 's retail price has been established using market research, and by going above the $\$ 10$ retail price, consumer demand would substantially diminish. Therefore, Crandon had to scrutinize the cost of the product and determine if any costs could be reduced and savings passed on to the retailer through a lower wholesale price. This could effectively increase margins for retailers, while keeping the same retail price.

\section{Café CRANDONTM's Costs}

As stated, Crandon is a fully diversified poultry company that is not in the business of packaging ingredients other than poultry. Consequently, the costs to Crandon were much higher than those of other companies whose plants were set up to handle all types of ingredients. Since Crandon did not have those capabilities, it had to outsource all components to be individually wrapped with the exception of chicken. Crandon had the capabilities to individually wrap the chicken due to one of its current product lines called SHORT CUTS ${ }^{\text {TM }}$ breast meat. Crandon could extend this line to produce the chicken for Café CRANDONTM HMRs. Appendix 3 indicates where all the components originated. Comparison costs of the ingredients for all three Café CRANDONTM HMRs are shown in the following charts.

\begin{tabular}{|c|c|c|c|c|}
\hline FETTUCCINE ALFREDO & \multicolumn{2}{|c|}{ CONSUMER } & \multicolumn{2}{c|}{ CRANDON } \\
\hline Ingredients & Unit & Total & Unit & Total \\
\hline Pasta (12 oz.) & $\$ 1.49$ & & $\$ .86$ & \\
\hline Alfredo (5 Brothers 17 oz.) & $\$ 2.49$ & & $\$ 1.52$ & \\
\hline Chicken Step Savor (8 oz.) & $\$ 3.52$ & $\$ 7.50$ & $\$ 2.76$ & $\$ 5.14$ \\
\hline Short Cuts Chicken Breast (6 oz.) & $\$ 3.00$ & $\$ 6.98$ & $\$ 1.98$ & $\$ 4.36$ \\
\hline
\end{tabular}

\begin{tabular}{|c|c|c|c|c|}
\hline STIR FRY & \multicolumn{2}{|c|}{ CONSUMER } & \multicolumn{2}{c|}{ CRANDON } \\
\hline Ingredients & Unit & Total & \multicolumn{2}{|c|}{ Unit } \\
\hline Raw Vegetables & $\$ 2.50$ & & $\$ 1.96$ & \\
\hline Sauce & $\$ 1.59$ & & $\$ .56$ & \\
\hline Rice & $\$ .99$ & & $\$ .28$ & \\
\hline Chicken Step Savor (8 oz.) & $\$ 3.52$ & $\$ 8.60$ & $\$ 2.76$ & $\$ 5.56$ \\
\hline Short Cuts Chicken Breast (6 oz.) & $\$ 3.00$ & $\$ 8.08$ & $\$ 1.98$ & $\$ 4.78$ \\
\hline
\end{tabular}

\begin{tabular}{|c|c|c|c|c|}
\hline FAJITA & \multicolumn{2}{|c|}{ CONSUMER } & \multicolumn{2}{|c|}{ CRANDON } \\
\hline Ingredients & Unit & Total & Unit & Total \\
\hline Refrigerated Tortillas & $\$ 1.89$ & & $\$ .76$ & \\
\hline Sour Cream & $\$ .75$ & & $\$ .27$ & \\
\hline Salsa (8 oz.) & $\$ 1.29$ & & $\$ .56$ & \\
\hline Seasoning & $\$ .79$ & & $\$ .18$ & \\
\hline Chicken Step Savor (8 oz.) & $\$ 3.52$ & 8.24 & $\$ 2.76$ & $\$ 4.53$ \\
\hline Short Cuts Chicken Breast (6 oz.) & $\$ 3.00$ & $\$ 7.72$ & $\$ 1.98$ & $\$ 3.75$ \\
\hline
\end{tabular}

Crandon's cost not only represented the actual cost of the products but an allocated cost to cover such things as overhead, advertising, shrinkage, etc. These allocations could not be changed since they were set up for all products produced by Crandon. Moreover, Crandon's accounting policies required that these costs not be considered in the cost reduction of the ingredients for Café CRANDON ${ }^{\mathrm{TM}}$. 


\section{Possible Cost Reductions}

Marketing expenses, which include television, radio, $\$ 1$ off coupons (at a percentage redemption rate), and demonstrations accounted for only 1.5 percent of Crandon's product costs. Due to Crandon's low margins and high raw material costs associated with producing Café CRANDONTM, the company chose to forego heavy advertising of the product.

Another marketing expense was the cost of packaging. Since Café CRANDONTM was a premium product, packaging could not be sacrificed as a cost-saving measure. Quality products require quality packaging, as product packaging creates consumer perceptions and expectations. Changing the types of colors or box patterns had virtually no impact on the current cost of packaging (less than .3\%).

One cost-saving measure was to market Café CRANDONTM HMRs as a frozen product or fresh/frozen type product. As originally conceived and marketed, Café CRANDON was an all-fresh product consistent with Crandon Farms' image as a producer of food that is fresh. In producing a premium frozen product, one would have to be careful not to damage the company's image and reputation.

Crandon did have some success with producing and marketing frozen products. Two years before it had introduced a product line called CRANDON FROZEN ${ }^{\mathrm{TM}}$, a line of individual quick frozen (IQF) chicken items in a resealable bag. Perhaps Café CRANDON ${ }^{\mathrm{TM}}$ HMRs could be marketed in this area without tarnishing the company's image. Since the image factor is out of the scope of this paper and this case, one can assume that Crandon's marketing department concluded that changing Café CRANDONTM from a fresh product to a frozen product would not significantly tarnish Crandon's goodwill.

Below would be the costs of the ingredients of the three Café CRANDONTM HMR sold as fresh or sold as a frozen product in the freezer section of the store.

\begin{tabular}{|c|c|c|c|c|}
\hline FETTUCCINE ALFREDO & \multicolumn{2}{|c|}{ FROZEN } & \multicolumn{2}{c|}{ FRESH } \\
\hline Ingredients & Unit & Total & Unit & Total \\
\hline Pasta (12 oz.) & $\$ .86$ & & $\$ .86$ & \\
\hline Alfredo (17 oz.) & $\$ .97$ & & $\$ 1.52$ & \\
\hline Chicken Step Savor (8 oz.) & $\$ 1.46$ & $\$ 3.29$ & 2.76 & $\$ 5.14$ \\
\hline Short Cuts Chicken Breast (6 oz.) & $\$ 1.98$ & $\$ 3.81$ & $\$ 1.98$ & $\$ 4.36$ \\
\hline
\end{tabular}

\begin{tabular}{|c|c|c|c|c|}
\hline STIR FRY & \multicolumn{2}{|c|}{ FROZEN } & \multicolumn{2}{c|}{ FRESH } \\
\hline Ingredients & Unit & Total & Unit & Total \\
\hline Raw Vegetables & $\$ .76$ & & $\$ 1.96$ & \\
\hline Sauce & $\$ .32$ & & $\$ .56$ & \\
\hline Rice & $\$ .25$ & & $\$ .28$ & \\
\hline Chicken Step Savor (8 oz.) & $\$ 1.46$ & $\$ 2.79$ & 2.76 & $\$ 5.56$ \\
\hline Short Cuts Chicken Breast (6 oz.) & $\$ 1.98$ & $\$ 3.31$ & $\$ 1.98$ & $\$ 4.78$ \\
\hline
\end{tabular}

\begin{tabular}{|c|c|c|c|c|}
\hline FAJITA & \multicolumn{2}{|c|}{ FROZEN } & \multicolumn{2}{c|}{ FRESH } \\
\hline Ingredients & Unit & Total & Unit & Total \\
\hline Refrigerated Tortillas & $\$ .56$ & & $\$ .76$ & \\
\hline Sour Cream & $\$ .22$ & & $\$ .27$ & \\
\hline Salsa (8 oz.) & $\$ .50$ & & $\$ .56$ & \\
\hline Seasoning & $\$ .18$ & & $\$ .18$ & \\
\hline Chicken Step Savor (8 oz.) & $\$ 1.46$ & $\$ 2.92$ & $\$ 2.76$ & $\$ 4.53$ \\
\hline Short Cuts Chicken Breast (6 oz.) & $\$ 1.98$ & $\$ 3.44$ & $\$ 1.98$ & $\$ 3.75$ \\
\hline
\end{tabular}


The costs of the frozen product contain the same overhead as do the fresh. These costs were derived from Crandon's known costs through its vendor network and using the company's current volume. These costs do not necessarily hold true to all companies since volume plays a role in all costs. It is important to note that frozen products have less shrinkage due to a reduction in spoilage and the increase in the product's shelf life. Also, frozen ingredients are more readily available than fresh products.

\section{Summary Of Cost Reductions}

All three Café CRANDONTM HMRs could have their costs reduced dramatically by changing the form of the product from fresh to frozen. By changing to a frozen product, the company would save on product costs from $\$ .31$ per unit for the Fajitas HMR to $\$ 1.47$ for the stir fry HMR, the largest savings of the three. The cost savings for the stir fry HMR would be $\$ 1.20$ and the shelf life of the vegetables would be increased from 14 days to indefinitely.

Some ingredients would not change much, if any. The seasoning and pasta would not have any change since it would be the same product. Little changes were noted with the rice, sour cream, and salsa. These products do not gain cost efficiencies when changing from a fresh to a frozen state.

Additional cost savings could be obtained by using cheaper chicken containing more fat, which the company also had available for use. However, this would be to the detriment of the company's SHORT CUTSTM breast meat product line. Other factors the company had to consider before switching to the cheaper chicken included: reduced quality, inadequate portion controls, outsourcing packaging of chicken, increased overhead, and the loss of SHORT CUTS ${ }^{\text {TM }}$ brand awareness. By using the company's SHORT CUTS ${ }^{\text {TM }}$ chicken, Crandon could possible attain processing plant efficiencies and plant capacity utilization would increase. This would lower costs to the company as a whole. Also, the company's trademark SHORT CUTS ${ }^{\mathrm{TM}}$ would be on the Café CRANDONTM package promoting the SHORT CUTS ${ }^{\mathrm{TM}}$ product line as well. This, in turn, would increase consumers' willingness to cross buy Crandon's products. Using the cheaper chicken would, in the long run, be more expensive and less effective than remaining with Crandon's SHORT CUTS ${ }^{\mathrm{TM}}$ chicken as an ingredient of Café CRANDONTM HMRs.

Purchasing fresh vegetables for use in producing Café CRANDONTM as a fresh food HMR would be much more problematic for the supply chain. Doing so would be much more expensive for the company, and it would be much more difficult to find suppliers willing to package products in a fresh form and deliver them on a timely basis to Crandon's Bridgewater, Virginia plant for processing. Logistics would be a problem as well as coordination of the supply chain activities. By changing to a frozen Café CRANDONTM HMR, the following margins could be maintained: Retail of $\$ 9.99$ per unit. FA weight $-2.00 \mathrm{lb}$., $\mathrm{F}=1.94 \mathrm{lb}$., $\mathrm{SF}=2.06 \mathrm{lb}$.

\begin{tabular}{|c|c|c|c|c|c|c|c|c|}
\hline & \multicolumn{3}{|c|}{ FRESH } & \multicolumn{4}{c|}{ FROZEN } \\
\hline Product & Cost & Cost/ unit & Gross $\$$ & Margin $\%$ & Cost & Cost/ unit & Gross \$ & Margin $\%$ \\
\hline FA & $\$ 3.49$ & $\$ 6.98$ & $\$ 3.01$ & $30 \%$ & $\$ 2.87$ & $\$ 5.74$ & $\$ 4.25$ & $43 \%$ \\
\hline F & $\$ 3.49$ & $\$ 6.77$ & $\$ 3.22$ & $32 \%$ & $\$ 2.87$ & $\$ 5.57$ & $\$ 4.42$ & $44 \%$ \\
\hline SF & $\$ 3.49$ & $\$ 7.19$ & $\$ 2.80$ & $28 \%$ & $\$ 2.87$ & $\$ 5.92$ & $\$ 4.07$ & $41 \%$ \\
\hline
\end{tabular}

\section{CONCLUSION}

Using target costing, Crandon Farms was able to proceed in a very methodical and rational way to avoid having a very good, but noncompetitive product in the HMR market. It began this process with satisfactory marketing research taking into consideration the wants and needs of the retail grocery chains and the consumers, both of which were extremely important to Crandon's success. A market price was determined for the product characteristics desired by consumers. Next, the demands of the retail grocers to maintain an acceptable gross margin were considered. This was Crandon's initial goal. 
Crandon next had to determine its own target profit. This was done through company cost/price allocation policies and profits were included in the costs of the ingredients allocated to each of the Café CRANDONTM HMRs. By adhering to such policies and including its profits in the ingredient costs, Crandon could focus on the retail price and retail grocer's required gross margin.

As a third step in the target costing process, Crandon had to calculate its allowable product costs for the Café CRANDONTM products. Given these allowable product costs, Crandon then sought out ways to produce the product for that cost. It was obvious that cost reductions could not be found were the company to continue producing a fresh HMR. The company had constraints placed on it in terms of the price (retail and wholesale), product characteristics, product quality, the supply chain, etc. Going through an iterative process and a cross-functional approach, the company found that it could meet the price, cost, and product constraints by changing to frozen HMRs. Had this change not be made, the target costing process would have dictated that Crandon drop the Café CRANDONTM product line altogether. The company would simply not be able to manufacture those products within the allowable product costs as calculated above.

The company will, no doubt, use other cost management techniques on an ongoing basis. Furthermore, the company's supply chain management will remain very active in the company's manufacturing, marketing, and logistics activities. Ideally, value engineering would have been, and would continue, to be used throughout the product development and production planning process and production facility changeover from the fresh HMR to the frozen. In the future when the HMR products will need to be changed or new Café CRANDON TM products added, target costing will enhance the product and manufacturing planning process to assure greater efficiency and profitability.

\section{REFERENCES}

1. Banham, Russ. Off Target? CFO. May 2000, Vol. 16 Issue 6. 127-131.

2. $\quad$ Brown, J. LMC Group HMR Seminar. LMC Group. Summer 1996.

3. Butsher, Stephan A. and Laker, Michael. Market-Driven Product Development. Marketing Management. Summer 2000, Vol. 9 Issue 2. 48-54.

4. Castellano, Joseph F. and Young, Saul. Speed Splasher: An Interactive, Team-Based Target Costing Exercise. Journal of Accounting Education. Spring 2003, Vol. 21 Issue 2. 149-156.

5. Clausing, Don P. Controlling Costs through Design (Letter to the Editor). Harvard Business Review. Mar./Apr. 1996, Vol. 74 Issue 2. p. 1.

6. Cooper, R. and Chew, W.B. Control Tomorrow's Cost through Today's Designs. Harvard Business Review. Jan./Feb. 1996, Vol. 74. 88-97.

7. Cooper, Robin and Slagmulder, Regine. Develop Profitable New Products with Target Costing. Sloan Management Review. Summer 1999, Vol. 40 Issue 4. 23-34.

8. Dekker, Henri and Smidt, Peter. A Survey of the Adoption and Use of Target Costing in Dutch Firms. International Journal of Production Economics. June 2003, Vol. 84 Issue 3. 293-306.

9. Ellram, Lisa M. Supply Management's Involvement in the Target Costing Process. European Journal of Purchasing \& Supply Management. Dec. 2002, Vol. 8 Issue 4. 235-245.

10. Ellram, Lisa M. Purchasing and Supply Management's Participation in the Target Costing Process. Journal of Supply Chain Management: A Global Review of Purchasing \& Supply. Spring 2000, Vol. 36 Issue 2. 3952.

11. Lockamy III, Archie and Smith, Wilbur I. Target Costing for Supply Chain Management: Criteria and Selection Industrial Management \& Data Systems. Vol. 100 Issue 5/6. 210-219.

12. Nicolini, D., Tomkins,C., Holti, R., Oldman, A., and Smalley, M. Can Target Costing and Whole Life Costing be Applied in the Construction Industry? British Journal of Management. Dec. 2000, Vol. 11 Issue 4. 303-325.

13. Packaged Facts. The Market for Meal Kits. Research Alert October 18, 1996.

14. Perry, John G. and Barnes, Martin. Target Cost Contracts: An Analysis of the Interplay between Fee, Target, Share and Price. Engineering Construction \& Architectural Management (Prior to 2003). June 2000, Vol. 7 Issue 2. 202-209.

15. $\quad$ Revolutionizing Retail. $\square$ Meat and Poultry Journal. August 1997: p. 14. 
16. Shank, John K. Target Costing as a Strategic Tool. Sloan Management Review. Fall 1999, Vol. 41 Issue 1. 73-83.

17. The Cutting Edge. $\square$ Meat and Poultry Journal. March 1998: p. 23.

\section{APPENDIX 1}

\begin{tabular}{|c|c|c|c|c|c|c|}
\hline $\begin{array}{c}\text { Product } \\
\text { Code }\end{array}$ & Description & $\begin{array}{l}\text { Kits/ } \\
\text { Cases }\end{array}$ & $\begin{array}{l}\text { Net Wt./ } \\
\text { Carton }\end{array}$ & $\begin{array}{c}\text { Case } \\
\text { Weight }\end{array}$ & $\begin{array}{l}\text { Case/ } \\
\text { Pallet }\end{array}$ & $\begin{array}{c}\text { Guaranteed } \\
\text { Freshness } \\
\end{array}$ \\
\hline 1200 & Fettuccine Alfredo & 4 & $2.00 \mathrm{lbs}$. & $8.00 \mathrm{lbs}$. & 120 & 17 days to first receiver \\
\hline 1205 & Fajitas & 4 & $1.94 \mathrm{lbs}$. & $7.76 \mathrm{lbs}$. & 120 & 9 days to first receiver \\
\hline 1210 & Stir Fry & 4 & $2.06 \mathrm{lbs}$. & $8.24 \mathrm{lbs}$. & 120 & 9 days to first receiver \\
\hline \multicolumn{7}{|c|}{$\begin{array}{l}\text { Fettuccine Alfredo } \\
6 \text { oz. CRANDON Italian Seasoned SHORT CUTS } \\
2 \text { packs ( } 5 \text { oz. each) Alfredo Sauce } \\
16 \text { oz. Fully Cooked Fettuccine Pasta } \\
\end{array}$} \\
\hline \multicolumn{7}{|c|}{$\begin{array}{l}\text { Fajitas } \\
6 \text { oz. CRANDON Mesquite Seasoned SHORT CUTS } \\
9 \text { - 6-inch Round Flour Tortillas } \\
3 \text { (1 oz. each) Non-Fat Sour Cream packets } \\
12 \text { oz. Roasted Peppers-Onions } \\
4 \text { oz. Picante Sauce }\end{array}$} \\
\hline $\begin{array}{l}\text { Stir Fry } \\
6 \text { oz. CRA } \\
12 \text { oz. Fres } \\
8 \text { oz. Lite } \\
2 \text { bags }(3.5 \\
\end{array}$ & $\begin{array}{l}\text { DON Original Roaste } \\
\text { Cut Vegetables } \\
\text { riyaki Sauce with Ses } \\
\text { z. each) Boil-in-Bag }\end{array}$ & Seasone & ORT CUTS & & & \\
\hline
\end{tabular}


NOTES 